\title{
Cloning, expressing and purification of recombinant C-terminal PMT of Pasteurella multocida
}

\author{
Hung K. Vu ${ }^{1 *}$, Thinh T. Nguyen ${ }^{1}$, Hang T. T. Trinh ${ }^{1}$, Thuy T.T. Nguyen ${ }^{1}$, \\ Giang T. T. Nguyen ${ }^{1}$, Anh T. T. Do ${ }^{2}$, \& Truong X. Nguyen ${ }^{1}$ \\ ${ }^{1}$ Institute of Veterinary Research and Development of Central Vietnam, Khanh Hoa, Vietnam \\ ${ }^{2}$ Biotechnology and Environment Institute, Nha Trang University, Khanh Hoa, Vietnam
}

\begin{abstract}
ARTICLE INFO
Research Paper

Received: March 19, 2019

Revised: September 10, 2019

Accepted: October 15, 2019

Keywords

Escherichia coli BL21

Pasteurella multocida

PMT

tPMT-C780

${ }^{*}$ Corresponding author

Vũ Khắc Hùng

Email: vukhac68@hotmail.com

Cited as: Vu, H. K., Nguyen, T. T., Trinh, H. T. T., Nguyen, T. T. T., Nguyen, G. T. T., Do, A. T. T., \& Nguyen, T. X. (2019). Cloning, expressing and purification of recombinant C-terminal PMT of Pasteurella multocida. The Journal of Agriculture and Development 18(5), 62-69.

Pasteurella multocida strains produce heat-stable toxin Pasteurella Multocida Toxin (PMT) which is the main virulence factor causing pasteurellosis in pigs. Therefore, PMT protein is considered as a promising candidate to study recombinant vaccine against pasteurellosis in pigs. In this study, we cloned the nucleotide sequence coding C-terminal fragment of PMT (tPMT-780), from acid amine 506 to acid amine 1285, into pRSET-A vector and expressed it on Escherichia coli BL21 bacteria. The SDS-PAGE result showed that tPMT-C780 was well-expressed by IPTG $1 \mathrm{mM}$ induction and determined to be insoluble protein, therefore it was purified by denaturation method using Ni-NTA beads. The protein elution samples contained only one protein band similar with the size of tPMT-C780 and positively reacted with PMT-specific antibody. These results suggested that we were successful in expressing and purifying C-terminal protein of PMT toxin, tPMT-C780. This is the primary material for further studies to produce recombinant vaccine against pasteurellosis in pigs.
\end{abstract}




\title{
Tạo dòng, biểu hiện và tinh sạch protein tái tổ hợp tPMT-C780 của Pasteurella multocida
}

\author{
Vũ Khắc Hùng ${ }^{1 *}$, Nguyễn Thị Thịnh $^{1}$, Trịnh Thị Thu Hằng ${ }^{1}$, Nguyễn Thị Thu Thủy $^{1}$, \\ Nguyễn Thị Thu Giang ${ }^{1}$, Đỗ Thị Trung Anh $^{2}$ \& Nguyễn Xuân Trường ${ }^{1}$ \\ ${ }^{1}$ Phân Viện Thú Y Miền Trung, Khánh Hòa \\ ${ }^{2}$ Viện Công Nghệ Sinh Học và Môi Trường, Trường Đại Học Nha Trang, Khánh Hòa
}

\section{THÔNG TIN BÀI BÁO}

Bài báo khoa học

Ngày nhận: 19/03/2019

Ngày chỉnh sửa: 10/09/2019

Ngày chấp nhận: 15/10/2019

\section{Từ khóa}

Escherichia coli BL21

Pasteurella multocida

PMT

tPMT-C780

*Tác giả liên hệ

Vũ Khắc Hùng

Email:vukhac68@hotmail.com

\section{TÓM TẮT}

Chủng độc lực Pasteurella multocida tiết ra nội độc tố chịu nhiệt Pasteurella Multocida Toxin (PMT), là yếu tố độc lực chủ yếu gây bệnh tụ huyết trùng trên lợn. Vì vậy, độc tố PMT là một yếu tố tiềm năng cho các nghiên cứu chế tạo vắc xin tái tổ hợp phòng bệnh tụ huyết trùng lợn. Trong nghiên cứu này, chúng tôi đã tiến hành tạo dòng, biểu hiện đoạn protein đầu C của PMT (tPMT-C780) (từ amino axit 506 dến 1285 của $\mathrm{PMT}$ ) trên vi khuẩn Escherichia coli BL21 bằng vector biểu hiện là plasmid pRSET-A. Kết quả SDS-PAGE cho thấy protein tái tổ hợp tPMT-C780 biểu hiện mạnh khi cảm ứng với IPTG $1 \mathrm{mM}$, và được xác định là protein không tan nên đã được tinh sạch theo phương pháp biến tính qua cột Ni-NTA. Dịch protein thu được sau khi tinh sạch chỉ chứa một vạch protein có kích thích tương đương với tPMT-C780 và cho phản ứng dương tính với kháng thể đặc hiệu PMT, chứng tỏ chúng tôi đã biểu hiện và tinh sạch thành công protein đầu $\mathrm{C}$ của độc tố $\mathrm{PMT}$. Đây là nguồn nguyên liệu ban đầu cho các nghiên cứu tiếp theo để chế tạo vắc xin tái tổ hợp phòng bệnh tụ huyết trùng lợn do vi khuẩn Pasteurella multocida gây ra.

\section{1. Đặt Vấn Đề}

Bệnh tụ huyết trùng trên lợn do một loại vi khuẩn đa hình thái tên gọi là Pasteurella. multocida gây ra. Bình thường chúng phát triển tốt trong chất nhầy có trên màng nhầy của mũi, amidal chứ không phải sống trên các biểu mô của mũi. Đây là một bệnh rất nguy hiểm đối với lợn, đặc biệt ở những cơ sở chăn nuôi tập trung công nghiệp bởi sự thiệt hại to lớn về kinh tế do bệnh gây nên (Le, 2015). Ngoài ra, tụ huyết trùng còn là một trong những bệnh thứ phát của hội chứng rối loạn hô hấp - sinh sản (tai xanh), làm cho bệnh ngày càng nghiêm trọng, và là nguyên nhân chính dẫn đến tỷ lệ chết cao. Ở Việt Nam, bệnh tụ huyết trùng là một trong những nguyên nhân chính gây chết lợn tại các ổ dịch tai xanh. Vi khuẩn $P$. multocida gây bệnh trên lợn thường thuộc nhóm $A, B$ và $D$ (Phan, 2000).

Trước đây, bệnh tụ huyết trùng lợn xảy ra mạnh ở các tỉnh phía Nam và xảy ra lẻ tẻ ở các tỉnh phía Bắc. Trong những năm 70 , có $80 \%$ số ổ dịch và $84 \%$ số thiệt hại gia súc do bệnh tụ huyết trùng thuộc các tỉnh phía Nam. Trong những năm 90, có 20 - 25 tỉnh thông báo có bệnh tụ huyết trùng lưu hành tại địa phương. Trong các năm từ 1996 - 1998 trên cả nước đã xảy ra 620 ổ dịch tụ huyết trùng lợn với 145.337 con mắc bệnh (Cao, 2002; Bui, 1998). Những năm gần đây, nhờ áp dụng tốt công tác phòng bệnh cũng như sử dụng vắc xin phòng bệnh hiệu quả, mặc dù không bùng phát thành dịch lớn, song hàng năm các ổ dịch tụ huyết trùng vẫn xảy ra và để lại hậu quả không nhỏ cho người chăn nuôi (Hoang, 2004; Nguyen, 2010).

Hiện nay, trên thị trường đang sử dụng hai loại vắc xin phòng bệnh tụ huyết trùng đó là vắc xin vô hoạt (vắc xin chết) và vắc xin sống nhược độc (vắc xin sống). Tuy nhiên, những loại vắc xin này có một số hạn chế nhất định như: vắc xin vô hoạt 
có độ dài miễn dịch ngắn, vắc xin sống nhược độc có thể biến đổi trở lại thành cường độc (Qureshi \& Saxena, 2014). Việc sử dụng công nghệ tái tổ hợp để phát triển vắc xin có thể sớm cách mạng hóa các loại vắc xin hiện tại. Kháng nguyên tái tổ hợp có thể được tổng hợp từ các hệ thống biểu hiện khác nhau sau khi kháng nguyên đích được xác định. Nhiều nghiên cứu sử dụng protein tái tổ hợp làm vắc xin tiểu phần đã khẳng định vắc xin đạt các chỉ tiêu an toàn và hiệu lực (Hussaini \& ctv., 2012). Do đó công nghệ tái tổ hợp trở lên đầy hứa hẹn và có thể được sử dụng để phát triển các loại vắc xin hiệu quả giúp bảo vệ chống lại hầu hết các chủng $P$. multocida. Để tạo nguồn nguyên liệu ban đầu cho việc chế tạo vắc xin tái tổ hợp phòng bệnh tụ huyết trùng do vi khuẩn P. multocida gây ra trên lợn, chúng tôi đã tiến hành tạo dòng, biểu hiện và tinh sạch protein tái tổ hợp tPMT-C780 trên vi khuẩn E. coli BL21.

\section{Vật Liệu và Phương Pháp Nghiên Cứu}

\subsection{Vật liệu}

Chủng vi sinh vật: Chủng vi khuẩn P.multocida phân lập được từ các mẫu bệnh phẩm của lợn mắc bệnh tụ huyết trùng mang gen mã hóa độc tố PMT, được sử dụng làm nguồn để nhân lên trình tự nucleotide mã hóa protein tPMT-C780.

Chủng biến nạp: E. coli DH5 $\alpha$ dùng để biến nạp trong tạo dòng, lưu giữ plasmid tái tổ hợp, E.coli BL21(DE3) dùng trong biểu hiện protein.

Vector: Vector pGEMT (Promega, Mỹ) là vector có hai đầu hở mang nucleotide $\mathrm{T}$, được sử dụng để tạo dòng gen sau khi khuếch đại bằng phản ứng PCR. Vector pRSET-A (V35120, Thermo Fisher Scientific). Vector biểu hiện này mang gen kháng ampicillin, có trình tự T7 promoter, cảm ứng sinh tổng hợp protein bằng Isopropyl $\beta$-D-1-thiogalactopyranoside (IPTG) và có trình tự mã hóa cho đuôi dung hợp 6xHistidine (His). Đuôi dung hợp -6xHis giúp tăng biểu hiện của protein mục tiêu và giúp tinh chế protein bằng hạt Ni-NTA.

Mồi phản ứng PCR: Các mồi cho phản ứng PCR sử dụng trong nghiên cứu này được tổng hợp bởi công ty First Base (Singapore). Các cặp mồi được gắn thêm trình tự cắt đặc hiệu của 2 enzyme $B a m H I$ và $S a c I$ ở đầu 5 '. Trình tự các cặp mồi như sau:

tPMT-780F: GATGGATCCGCGAGAAATTA CTGACG
tPMT-780R: GCGGAGCTCTAGTGCTCTTG TTAAG

T7 promoter: TAATACGACTCACTATAGGG

\subsection{Tao dòng plasmid pRSET-A/tPMT-C780}

DNA tổng số của vi khuẩn $P$. multocida mang gen mã hóa độc tố PMT được tách chiết bằng bộ kít Wizard Genomic DNA Purification (Qiagen) để làm khuôn cho phản ứng PCR nhân gen mã hóa protein tPMT-C780. Phản ứng PCR sử dụng cặp mồi tPMT-780F, tPMT-780R với chu trình nhiệt: $95^{0} \mathrm{C} / 3$ phút, 35 chu kỳ của $95^{\circ} \mathrm{C} / 30$ giây, $60^{0} \mathrm{C} / 30$ giây, $72^{0} \mathrm{C} / 60$ giây, sau đó xử lý $72^{0} \mathrm{C} / 10$ phút và giữ ở $4^{0} \mathrm{C}$. Sản phẩm $\mathrm{PCR}$ sau đó được nối với pGEMT và biến nạp vào E.coli $\mathrm{DH} 5 \alpha$. Sau khi kiểm tra trình tự, đoạn tPMT-780 được cắt khỏi vector pGEMT bằng enzyme BamHI (New England Biolabs, \#R0136S) và SacI (New England Biolabs, \#R0138S). Vector pRSET-A cũng được cắt với enzyme $B a m H I$ và $S a c I$. Đoạn tPMT-780 sau khi tinh sạch được nối với vector pRSET-A. Plasmid tạo thành được biến nạp vào E.coli $\mathrm{DH} 5 \alpha$. Những khuẩn lạc tạo thành sau đó được sàng lọc bằng phản ứng colony PCR bằng mồi $\mathrm{T} 7$ promoter và $\mathrm{tPMT}-780 \mathrm{R}$ với chu trình nhiệt: $95^{0} \mathrm{C} / 3$ phút, 40 chu kỳ của $95^{\circ} \mathrm{C} / 30$ giây, $60^{\circ} \mathrm{C} / 30$ giây, $72^{0} \mathrm{C} / 60$ giây, sau đó xử lý $72^{0} \mathrm{C} / 10$ phút và giữ ở $4^{0} \mathrm{C}$.

Sau khi sàng lọc, những khuẩn lạc mang plasmid pRSET-A/ tPMT-780 được nuôi cấy, tách chiết plasmid bằng bộ kit QIAprep Spin Miniprep Kit (QIAGEN, Cat. No. 27149) và kiểm tra đoạn cài bằng cách cắt lại với enzyme giới hạn $B a m H I$ và $S a c I$ đã sử dụng trước đó.

\subsection{Biểu hiện protein tPMT-C780 trong E.coli BL21(DE3)}

Plasmid pRSET-A/tPMT-780 được biến nạp vào dòng E.coli BL21(DE3) dể biểu hiện protein. Các khuẩn lạc được sàng lọc trên môi trường LB có bổ sung $100 \mu \mathrm{g} / \mathrm{mL}$ ampicillin. Các khuẩn lạc được kiểm tra lại bằng phản ứng colony $\mathrm{PCR}$ bằng mồi $\mathrm{T} 7$ promotor và tPMT-780R với chu trình nhiệt: $95^{\circ} \mathrm{C} / 3$ phút, 40 chu kỳ của $95^{\circ} \mathrm{C} / 30$ giây, $60^{\circ} \mathrm{C} / 30$ giây, $72^{\circ} \mathrm{C} / 60$ giây, sau đó xử lý $72^{0} \mathrm{C} / 10$ phút và giữ ở $4{ }^{0} \mathrm{C}$.

Khuẩn lạc mang plasmid pRSET-A/tPMT-780 được nuôi lắc 200 vòng/phút trong $200 \mathrm{~mL}$ môi trường $\mathrm{LB}$ có bổ sung $100 \mu \mathrm{g} / \mathrm{mL}$ ampicilin và cảm ứng IPTG 1 mM, ethanol 1 - 3\% tại $\mathrm{OD}_{600}$ 
$=0,7$, thời gian cảm ứng 18 giờ, nhiệt độ nuôi $28^{0} \mathrm{C}$.

\subsection{Kiểm tra tính tan và tinh sạch protein}

Để kiểm tra tính tan của protein được biểu hiện, chúng tôi tiến hành phá tế bào trong dung dịch dệm phosphate buffer saline (PBS), lysozyme $1 \mathrm{mg} / \mathrm{mL}$, chứa và không chứa urea 6 M. Sau đó, tế bào được xử lý bằng sóng siêu âm tần số $20 \mathrm{KHz}$, trong 10 phút (rung 10 giây, nghỉ 10 giây). Dung dịch sau đó được ly tâm 13000 vòng/phút, 15 phút, dịch và cặn được thu lại để kiểm tra trên gel SDS-PAGE.

Protein sau đó được tinh sạch bằng phương pháp sắc ký ái lực sử dụng hạt Ni-NTA (Promega). Protein bám trên hạt Ni-NTA sau đó được rửa và thu lại bằng dung dịch Imidazole 250 $\mathrm{mM}$.

\subsection{Phản ứng Western blot}

Dịch protein thu được sau khi tinh sạch được chạy phân tách trên gel SDS-acrylamide 10\%, sau đó được chuyển sang màng nitrocellulose bằng hệ thống máy chuyển màng ECL semi-dry blotters $\left(\right.$ Amersham $^{\mathrm{TM}}$ ) tại điện thế $25 \mathrm{~V}$ trong 1 giờ. Màng chứa protein sau khi được ủ trong dung dịch sữa skimmilk $5 \%$ trong 1 giờ tại nhiệt dộ phòng sẽ được ủ lắc với dung dịch chứa kháng thể sơ cấp đặc hiệu của PMT với tỷ lệ pha loãng là 1: 5000 (Anti-Pasteurella multocida Toxin antibody, rabbit polyclonal, BioAcademia 01-507) tại $4^{0} \mathrm{C}$ qua đêm. Sau khi rửa 3 lần với dung dịch rửa TPBS (PBS, Tween 20 0,1\%), màng được ủ lắc với dung dịch chứa kháng thể thứ cấp (horseradish peroxidase secondary rabbit antibody, AmershamTM) với tỷ lệ pha loãng 1:10.000 tại nhiệt độ phòng. Sau 1 giờ, màng được rửa 5 lần với dung dịch rửa và ngâm vào dung dịch thuốc nhuộm $3,3,5,5$-Tetramethylbenzidine (TMB) dể đọc kết quả.

\section{Kết Quả và Thảo Luận}

\subsection{Kết quả tạo dòng pRSET-A/tPMT-780}

Để biểu hiện được protein đầu $\mathrm{C}$ của $\mathrm{PMT}$, trước hết chúng tôi phải có được trình tự gen mã hóa cho trình tự protein này. Gen tPMT-780 được thiết kế mã hóa cho trình tự amino axit từ 506 đến 1285 của PMT protein. Gen này được nhân lên bằng phản ứng $\mathrm{PCR}$ từ $\mathrm{DNA}$ tổng số của vi

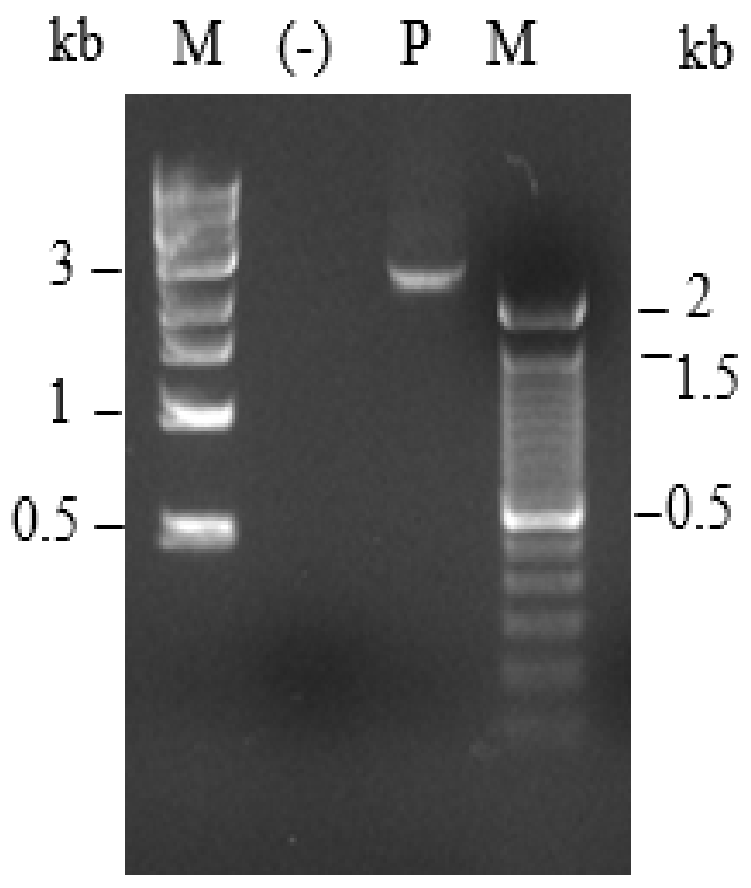

Hình 1. Kết quả PCR nhân gen tPMT-C780 từ DNA

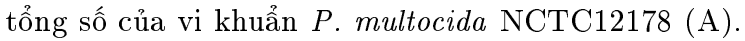
$\mathrm{M}$ : thang chuẩn DNA; (-): đối chứng âm, $\mathrm{P}$ : sản phẩm $\mathrm{PCR}$ gen tPMT-C780.

khuẩn P. multocida đã được xác định mang gen mã hóa độc tố PMT. Kết quả hình 1 cho thấy, chúng tôi đã nhân lên được trình tự gen có kích thước tương đương kích thước của tPMT-C780 là 2337bp. Như vậy, có thể chúng tôi đã khuếch đại thành công đoạn gen tPMT-C780 (Hình 1).

Sản phẩm PCR thu được sau đó được lai tạo dòng với vector pGEMT. Kết quả kiểm tra plasmid pGEMT/tPMT-780 bằng cặp mồi tPMTC780F/PMT-C780R (Hình 2) cho thấy, chúng tôi thu được nhiều khuẩn lạc cho kết quả dương tính với gen tPMT-C780. Các khuẩn lạc này được tách chiết thu plasmid và gửi giải trình tự. Kết quả cho thâyy chúng tôi đã thu được trình tự tương đồng $100 \%$ với trình tự gốc mã hóa tPMT-C780. Như vậy, chúng tôi đã tạo dòng thành công gen tPMT-C780 từ genome vi khuẩn $P$. multocida.

Đoạn gen tPMT-C780 sau đó được cắt từ vec-

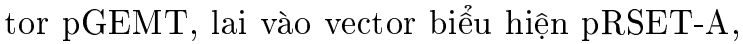
và biến nạp vào vi khuẩn $E$.coli $\mathrm{DH} 5 \alpha$. Các khuẩn lạc mọc trên môi trường LB chứa ampicillin 100 $\mu \mathrm{g} / \mathrm{mL}$ được sàng lọc bằng phản ứng colony $\mathrm{PCR}$ với mồi $\mathrm{T} 7$ promoter và tPMT-780R. Kết quả thể hiện ở Hình 3 cho thấy, chúng tôi đã thu được những khuẩn lạc dương tính với 1 vạch DNA 


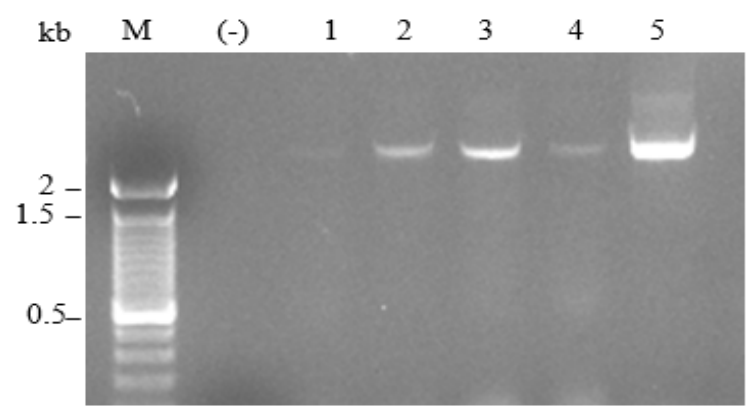

Hình 2. Kết quả colony $\mathrm{PCR}$ kiểm tra gen tPMTC780 trong plasmid pGEMT. M: thang chuẩn DNA; (-): đối chứng âm, 1-5: 5 khuẩn lạc E.coli DH5a /pGEMT/tPMT-C780.

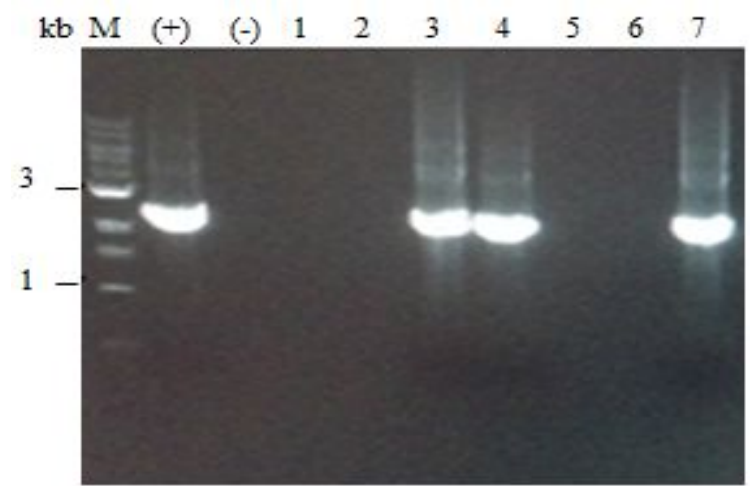

Hình 3. PCR kiểm tra đoạn gen tPMT-C780 trên plasmid pRSET-A trong vi khuẩn E.coli $\mathrm{DH} 5 \alpha$. M: thang chuẩn DNA, $(+)$ : đối chứng dương với khuôn là plasmid pGEMT/tPMT-C780, (-): đối chứng âm; 1-7: khuẩn lạc E.coli DH5 $\alpha$ 1-7.

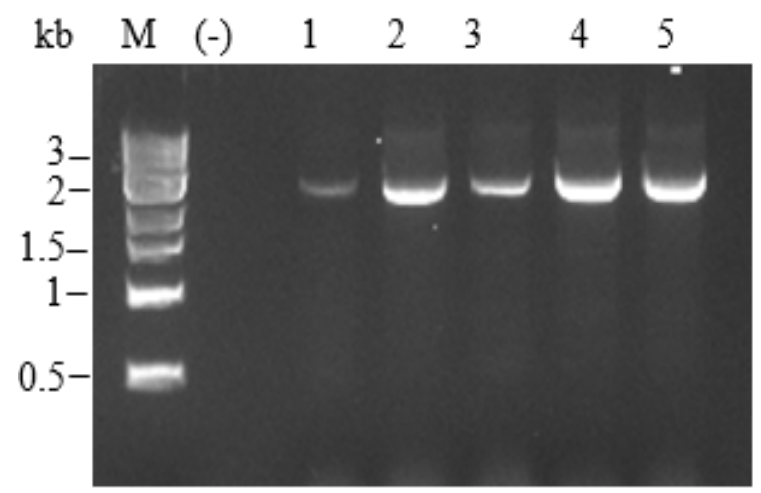

Hình 4. Kết quả colony PCR kiểm tra sự có mặt của plasmid pRSET-A/tPMT-C780 sau khi cấy chuyển 5 ngày liên tiếp. M: Thang chuẩn DNA, (+): đối chứng dương với khuôn là plasmid pGEMT/tPMT-C780, (): đối chứng âm, 1-5: khuẩn lạc E.coli BL21/pRSETA/tPMT-C780 tại các ngày cấy chuyển 1 dến 5 . rõ nét tương đương kích thước $2337 \mathrm{bp}$ của gen tPMT-780. Như vậy chúng tôi đã tạo dòng được gen tPMT-780 trên vector biểu hiện pRSET-A.

Plasmid từ những khuẩn lạc dương tính được biến nạp vào E.coli BL21(DE3) và kiểm tra sự tồn tại qua nhiều đời bằng cách cấy chuyển 5 ngày liên tiếp trên môi trường thạch LB chứa 100 $\mu \mathrm{g} / \mathrm{mL}$ ampicillin ở $37^{0} \mathrm{C}$. Kết quả kiểm tra bằng colony PCR (Hình 4) cho thấy plasmid pRSETA/tPMT-C780 ổn định và tồn tại qua nhiều lần cấy chuyển. Như vậy chúng tôi đã tạo dòng thành công đoạn gen tPMT-C780 trên plasmid biểu hiện $\mathrm{pRSET}-\mathrm{A}$, plasmid này ổn định và tồn tại qua nhiều thế hệ trên E.coli BL21(DE3).

\subsection{Kết quả biểu hiện protein tPMT-C780 ở vi khuẩn E.coli BL21}

Vi khuẩn E.coli BL21/pRSET-A/tPMT-C780 được nuôi cấy ở $37^{0} \mathrm{C}$ cho đến khi đạt mật độ $\mathrm{OD} \sim 0,7$, thì được cảm ứng với IPTG $1 \mathrm{mM}$ và ethanol nồng độ $1 \%$ và $3 \%$ tại $28^{0} \mathrm{C}$ trong 18 giờ. Kết quả SDS kiểm tra biểu hiện protein tPMTC780 được thể hiện như Hình 5.

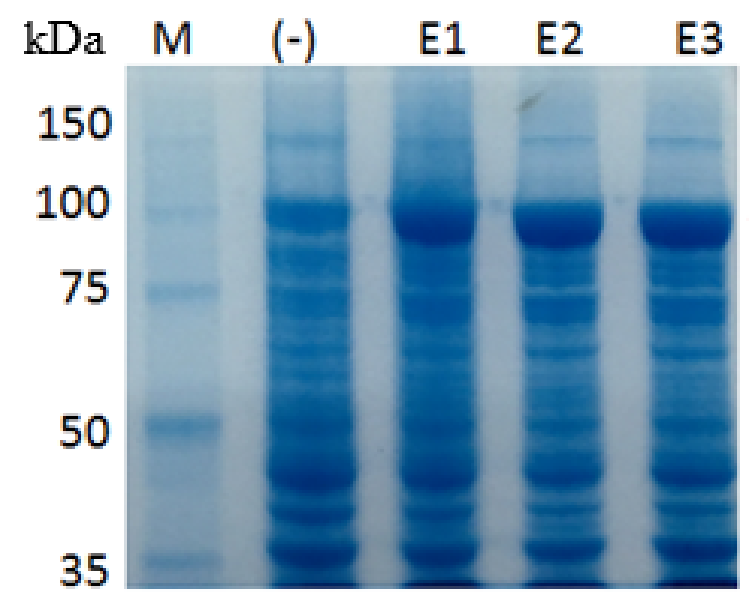

Hình 5. Biểu hiện protein tPMT-C780 trên E.coli BL21. M: Thang protein chuẩn, (-): mẫu không cảm ứng, E1: cảm ứng IPTG $1 \mathrm{mM}$; E2: cảm ứng IPTG $1 \mathrm{mM}+$ Ethanol 1\%; E3: cảm ứng IPTG $1 \mathrm{mM}+$ ethanol $3 \%$.

Kết quả biểu hiện cho thấy tPMT-C780 được biểu hiện tốt khi cảm ứng với IPTG $1 \mathrm{mM}$, và không có sự khác biệt khi kết hợp cảm ứng IPTG với ethanol $1-3 \%$. Protein biểu hiện mạnh, có kích thước khoảng $100 \mathrm{kDa}$, tương đương với kích thước protein tPMT-C780 mà chúng tôi thiết kế. Như vậy, tPMT-C780 đã được tạo dòng, biểu hiện 
thành công, và có thể sử dụng để tiến hành các thí nghiệm tinh sạch tiếp theo.

\subsection{Kết quả kiểm tra tính tan và tinh sạch protein}

Để tinh sạch, protein biểu hiện cần được hòa tan trong dung dịch để gắn lên hạt Ni-NTA. Các nghiên cứu trước đây cho thấy, nhiều protein tái tổ hợp sau khi được biểu hiện là protein không tan, phần lớn nằm trong cặn tế bào. Vì vậy, các protein này được hòa tan biến tính trong dung dịch urea $6-8 \mathrm{M}$ trước khi tiến hành các bước tinh sạch. Trong nghiên cứu này, chúng tôi tiến hành ủ sinh khối tế bào E.coli BL21/pRSET-A/tPMT-C780 2 giờ, tại $4^{0} \mathrm{C}$ trong dung dịch dệm phosphate buffer saline (PBS), lysozyme $1 \mathrm{mg} / \mathrm{ml}$, chứa và không chứa urea $6 \mathrm{M}$. Sau đó, tế bào được phá vỡ bằng sóng siêu âm, ly tâm để phân tách dịch và cặn tế bào, và tiến hành phân tách trên gel SDS-PAGE. Kết quả thể hiện ở Hình 6 cho thây, protein biểu hiện chủ yếu nằm trong cặn tế bào khi phá tế bào trong dung dịch không chứa urea 6 M. Như vậy, tPMT-C780 là protein không hòa tan, nên chúng tôi phải sử dụng urea $6 \mathrm{M}$ dể hòa tan biến tính protein này vào dung dịch để tiến hành các bước tinh sạch tiếp theo bằng phương pháp sắc ký ái lực sử dụng hạt Ni-NTA.

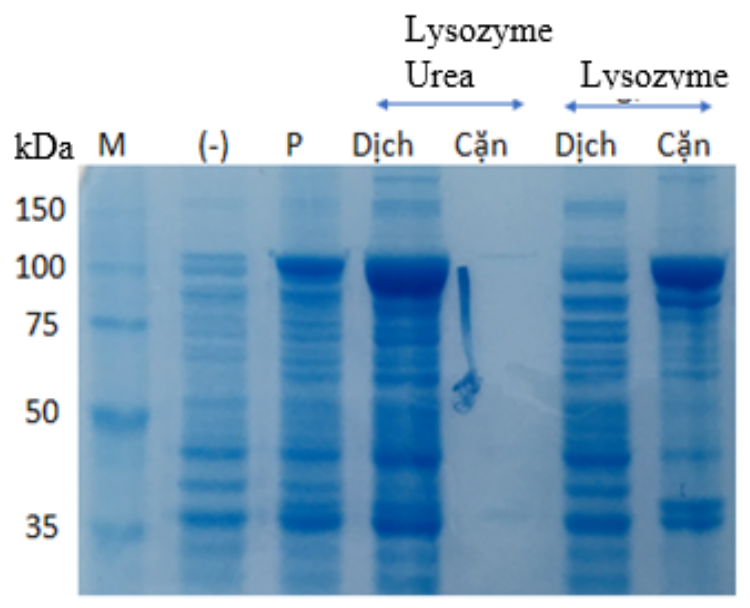

Hình 6. Phân bố protein tPMT-C780 trong dịch và cặn tế bào. $\mathrm{M}$ : thang protein chuẩn, (-): mẫu protein E.coli BL21/pRSET-A/tPMT-C780 không cảm ứng, P: protein E.coli BL21/pRSET-A/tPMT-C708 cảm ứng IPTG $1 \mathrm{mM}$ trước khi phá tế bào.

Dịch thu được sau khi phá tế bào bằng dung dịch đệm PBS, lysozyme $1 \mathrm{mg} / \mathrm{mL}$ chứa urea $6 \mathrm{M}$ được ủ với hạt Ni-NTA ở $4^{0} \mathrm{C}$ trong 2 giờ để gắn His-tPMT-C780 protein lên hạt Ni-NTA. Sau đó, hạt Ni-NTA được ly tâm, thu, và rửa 5 lần với dung dịch đệm PBS chứa urea $6 \mathrm{M}$, và imidazol $20 \mathrm{mM}$ để loại bỏ các protein không mong muốn. Hạt Ni-NTA sau đó được ủ với dung dịch PBS chứa urea $6 \mathrm{M}$ và imidazole $250 \mathrm{mM}$ trong 30 phút để thu lại His- tPMT-C780 từ hạt Ni-NTA. Kết quả SDS-PAGE cho thấy, dung dịch protein thu được sau tinh sạch chỉ chứa 1 vạch protein có kích thước tương đương với protein tPMT-C780 (Hình 7). Kết quả này cho thấy, protein tPMTC780 đã được tinh sạch thành công, và đạt yêu cầu về độ sạch.

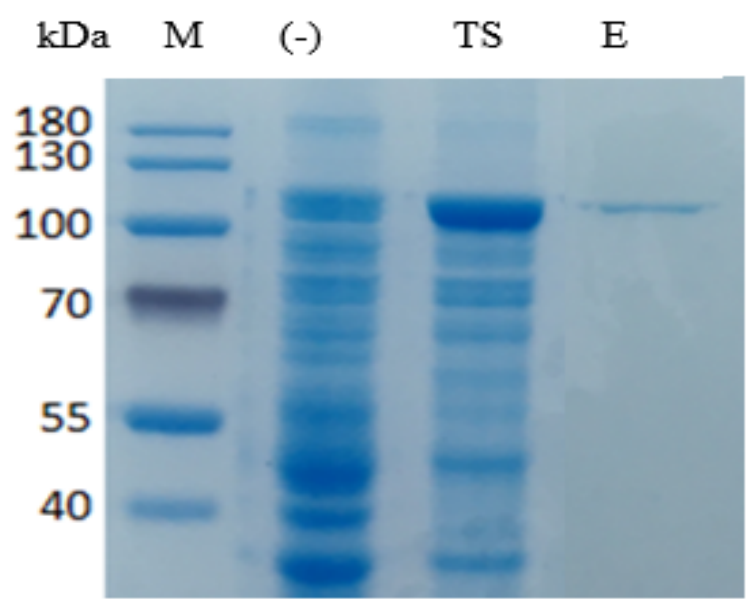

Hình 7. Kết quả tinh sạch protein tPMT-C780. M: thang protein chuẩn, (-): protein tổng số không cảm ứng, TS: protein tổng số cảm ứng IPTG; E: mẫu protein sau khi tinh sạch.

\subsection{Kiểm tra protein tinh sạch bằng phản ứng western blot}

Để kiểm tra protein đã biểu hiện và được tinh sạch có chính xác là trình tự đầu $\mathrm{C}$ của độc tố PMT hay không, chúng tôi phân tách dịch protein tinh sạch trên gel SDS-acrylamide, sau đó thực hiện phản ứng lai với kháng thể đặc hiệu của độc tố PMT (Anti-Pasteurella mulcosida Toxin antibody, rabbit polyclonal, BioAcademia). Tương tác giữa kháng thể và protein được xác định bằng phản ứng mầu giữa enzyme peroxidase và cơ chất TMB. Kết quả thể hiện ở Hình 8 cho thấy, protein tinh sạch tại vị trí hơn $100 \mathrm{kDa}$ có phản ứng dương tính mạnh với kháng thể đặc hiệu PMT. Như vậy, protein biểu hiện và tinh sạch mà chúng tôi thu được chính xác là protein đầu $\mathrm{C}$ của $\mathrm{PMT}$ (tPMT-C780) mà chúng tôi mong muốn. 


\section{$\mathrm{kDa} \quad \mathrm{M} \quad \mathrm{tPMT}-\mathrm{C} 780$}

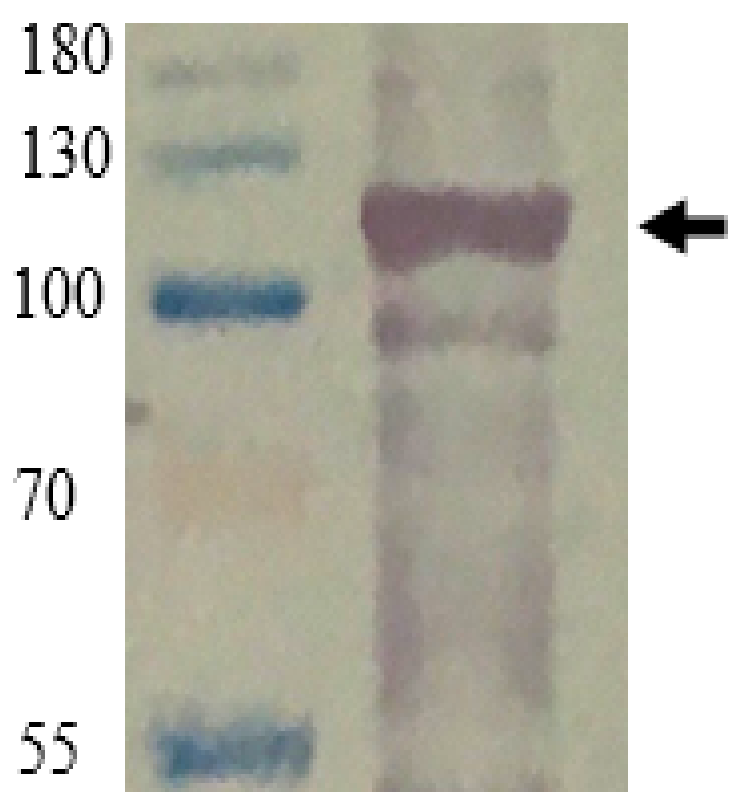

Hình 8. Kết quả western blot của protein tinh sạch với kháng thể đặc hiệu PMT (Anti-Pasteurella mulcosida Toxin antibody, rabbit polyclonal, BioAcademia). M: thang chuẩn protein (Thermo Scientific); tPMT-C780: mẫu protein tinh sạch. Mũi tên chỉ band vị trí của tPMT-C780.

\subsection{Thảo luận}

PMT là gen độc tố chính của $P$. multocida, rất nhiều tác giả đã dựa trên trình tự của gen PMT để nghiên cứu độc lực của $P$. multocida cũng như tìm hướng sản xuất vắc xin tái tổ hợp từ độc tố này (Kim \& ctv., 2006). Protein PMT gồm 1285 amino axit (García \& ctv., 2011), là một dạng ngoại độc tố gây hoại tử niêm mạc (demonecrotic toxin ), gồm: đầu (PMT- N) vị trí từ amino axit 1 đến 568 là vùng liên kết thụ thể và vận chuyển độc tố vào tế bào vật chủ; đầu $\mathrm{C}(\mathrm{PMT}-\mathrm{C})$ có vai trò tương tác và sửa đổi các protein $\mathrm{G}$ trong tế bào, gây độc cho tế bào vật chủ (Busch \& ctv., 2001; Okay \& ctv., 2012).

Vắc xin tái tổ hợp dựa trên độc tố PMT có đáp ứng miễn dịch tốt và an toàn hơn so với vắc xin toàn khuẩn (Freddy \& ctv., 2004; Hussaini \& ctv., 2011). Kết quả nghiên cứu của một số tác giả trước đây cho thấy, protein tái tổ hợp tạo ra từ gen PMT đều tạo ra miễn dịch dịch thể và miễn dịch trung gian tế bào (Liao \& ctv., 2006; Lee \& Woo, 2010; Lee \& ctv., 2012). Theo kết quả nghiên cứu của Lee \& Woo (2010), trình tự đầu $\mathrm{C}$ của PMT có khả năng gây đáp ứng miễn dịch mạnh và có khả năng bảo hộ tốt trên động vật thí nghiệm Lee \& Woo (2010). Vì vậy, trong nghiên cứu này, chúng tôi đã tạo dòng, biểu hiện và tinh sạch trình tự đầu $\mathrm{C}$ từ amino aixt 506 đến 1285 của protein PMT. Kết quả ban đầu cho thấy, chúng tôi đã tổng hợp và tinh sạch được protein tPMT-C780, đây là cơ sở để chúng tôi tiến hành các nghiên cứu tiếp theo chế tạo vắc xin tái tổ hợp phòng bệnh tụ huyết trùng trên lợn.

\section{Kết Luận}

Chúng tôi đã tạo dòng, biểu hiện và tinh sạch thành công protein tái tổ hợp tPMT-C708, là trình tự protein đầu $\mathrm{C}$ từ amino axit 506 đến 1285 của độc tố vi khuẩn $P$. multocida, PMT. Kết quả này là thành công bước đầu để chúng tôi tiến hành chế tạo vắc xin tái tổ hợp phòng bệnh tụ huyết trùng trên lợn.

\section{Cam Đoan}

Chúng tôi cam đoan tất cả các tác giả đều đồng ý với nội dung của bài báo này.

\section{Lời Cảm Ơn}

Nghiên cứu được cấp kinh phí bởi chương trình Công nghệ Sinh học, Bộ Nông nghiệp và Phát triển nông thôn.

\section{Tài Liệu Tham Khảo (References)}

Bui, H. Q. (1998). Characteristics of pasteurellosis in Vietnam in recent years. Veterinary Sciences and Techniques 5(1), 9-94.

Cao, H. V. (2002). Epidemiology of pasteurellosis in buffaloes, cows, and swines in Dak Lak, and some preventive and treatment measures. (Unpublished doctoral dissertation) Vietnam National University of Agriculture. Ha Noi, Vietnam.

Freddy, H., Frank, P., Koen, C., Dominiek, M., Richard, D., \& Annemie, D. (2004). Efficacy of vaccines against bacterial diseases in swine. Veterinary Microbiology $100,255-268$.

García, N., Fernández-Garayzábal, J. F., Goyache, J., Domíngue, L. \& Vela, A. I. (2011). Associations between biovar and virulence factor genes in Pasteurella multocida isolates from pigs in Spain. Veterinary Record 169, 362-366. 
Hoang, H. D. (2004). Study epidemiological characteristics and factors influencing pasteurellosis in buffaloes, and cows in Bac Giang (1995-2001), and suggest preventive and treatment measures. (Unpublished doctoral dissertation). Hanoi Agriculture and Forestry University, Ha Noi, Vietnam.

Hussaini, J., Abdullahi, M. A., \& Ismail, S. (2012). Expression and immunogenicity determination ofrecombinant clone of Pasteurella multocida serotype B against Haemorrhagic septicaemia: Towards a vaccine development. Journal of Animal and Veterinary Advances 11 (3), 351-356.

Hussaini, J., Nazmul, M. H. M., Abdullah, M. A., \& Ismail S. (2011). Recombinant clone ABA392 protects laboratory animals from Pasteurella multocida serotype B. African Journal Microbiology Research 5, 2596-2599.

Kim, T. J., Lee, J. I., \& Lee, B. J. (2006). Development of a PMT Gene Knock-out Mutant of Pasteurella multocida and evaluation of its protective effects. Journal of Microbiology 44(3), 320-326.

Le, N. V. (2015). Diseases in Vietnam swines: Effective treatment measures. Ho Chi Minh City, Vietnam: Agricultural Publishing House.

Lee, J., \& Woo H. J. (2010). Antigenicity of Partial Fragments of Recombinant Pasteurella multocida Toxin. Journal of Microbiology and Biotechnology 20(12), 1756-1763.
Lee, K. E., Jeoung, H. Y., Lee, J. Y., Lee, M. H., Choi, H. W., Chang, K. S., Oh, Y. H., \& An, D. J. (2012). Phenotypic characterization and random amplified polymorphic DNA (RAPD) analysis of Pasteurella multocida isolated from Korean Pigs. Bacteriology 74(5), 567-573.

Liao, C. M., Huang, C., Hsuan, S. L., Chen, Z. W., Lee, W. C., Liu, C. I., Winton, J. R., \& Chien, M. S. (2006). Immunogenicity and efficacy of three recombinant subunit Pasteurella multocida toxin vaccines against progressive atrophic rhinitis in pigs. Vaccine 24(1), 27-35.

Nguyen, D. T. K. (2010). Determination of Pasteurella multocida causing pasteurellosis in buffaloes, cows in Ha Giang, Cao Bang, and initial tests of autovaccine. (Unpublished master's thesis). Thai Nguyen University, Thai Nguyen, Vietnam.

Okay, S., Özcengiz, E., Gursel, I., \& Özcengiz, G. (2012). Immunogenicity and protective efficacy of the recombinant Pasteurella lipoprotein E and outer membrane protein $\mathrm{H}$ from Pasteurella multocida A: 3 in mice. Research In Veterinary Science 93, 1261-1265.

Phan, P. T. (2000). Pasteurellosis of animal and poultry and its control measures. Veterinary Sciences and Techniques 7(2), 78-86.

Qureshi, S., \& Saxena, H. M. (2014). Estimation of titers of antibody against Pasteurella multocida in cattle vaccinated with haemorrhagic septicemia alum precipitated vaccine. Veterinary World 7(4), 224-228. 